\title{
Revisiting Sino-Mozambican Cooperation: China's Inroads into the Agriculture and Forestry Sectors
}

\author{
By Mafalda Ferreira Piçarra \\ University of Bristol, U.K.
}

This article is a shortened version of a CCS discussion paper in preparation.

\section{Introduction}

Since Mozambique became an independent state in 1975, its development trajectory has been shaped by international and internal events (Alden, 2001:8). In the first decade after independence, the Government of Mozambique (GoM) implemented a Marxist-oriented programme, which did not produce the expected outcomes (Latham, 1981:69; Abrahamsson and Nilsson, 1995: 28-30). In addition, Mozambique's colonial past, governance inexperience, insufficient capital, poor infrastructure and unskilled population have limited the state's capacity to develop strong governmental institutions, a solid national economy, and a cohesive national identity. Also, the internal conflict started by the Mozambican National Resistance (Renamo) rebel movement against the Liberation Front of Mozambique government (Frelimo) lasted for sixteen years and destroyed much of the infrastructure left from the colonial period ( Hall and Young, 1997: 115-137).To support a declining economic, political and social structure, the government was left with no alternative but to turn to Western states and International Financial Institutions (IFIs) for support by the mid-1980s ( Manning, 2002: 55-6; Pitcher, 2002:103-114; Hanlon, 1991: 28-9; Hanlon, 1996: 16). The transition from a phase in which Mozambique had relative autonomy to one in which international organisations became deeply involved in the state's development has had innumerable implications (Ottaway, 1988: 222; Manning, 2002: 123-132).

I Financial and technical assistance of donors and IFIs has interfered with the government's development programmes, the allocation and uses of its funds, and the objectives it has to meet.

On the one hand, financial and technical assistance of donors and IFIs has interfered with the government's development programmes, the allocation and uses of its funds, and the objectives it has to meet (Plank, 1993: 441; Batley, 2005; Arndt et al. 2007). This has constrained the state's room for manoeuvre (Newitt, 2002: 227). On the other hand, the availability of financial resources which were almost inexistent until the mid-1980s has facilitated the promotion of patrimonial ties and the prioritisation of personal economic and political interests over national welfare.

At the beginning of the twenty-first century, the rise of China in Africa brought subSaharan African states into the spotlight, showed China's potential for becoming a driver of change in the development of sub-Saharan African states, and exposed a new dynamics in international affairs. The implications of China's involvement in subSaharan African states development have been intensively debated (Broadman, 2006; Gomes, 2007; Manji and Marks, 2007; Mawdsley, 2008; Bräutigam, 2009; 'The Chinese Are Coming' by the BBC, 2011; Oxford University China Africa Network 
conference on 'Chinese Investment and African Agency', 2011).

Mozambique has also been benefiting from stronger economic and diplomatic relations with China. As China seeks to secure access to natural, mineral, agricultural and energy resources, it uses a range of development and financial assistance instruments to promote development in countries like Mozambique and to cement ties. Mozambique's choice of development partners can sustain the GoM with alternative sources of aid, trade and investment, and with increasing economic opportunities and benefits. However, Mozambique's ruling elite can also use these new external resources to pursue elite projects, to sustain clientelistic networks, and to promote self-aggrandisement. Moreover, China can create new dependency linkages or impose conditions by linking aid to trade, investments and joint ventures with Mainland China (Taylor, 2011: 51-2).

This article seeks to discuss and shed light into China's interests and impact on sectors relevant for Mozambique's development. It also seeks to examine how China's growing involvement in Mozambique's agriculture and forestry sectors collude or clash with Mozambican development policies. Finally, it seeks to analyse the role the Mozambican ruling elite plays in shaping Sino-Mozambican cooperation.

17 Agriculture and forestry are priority sectors in Mozambique's development policies and are key to boosting sustainable development and reducing poverty.

\section{Analysing China's inroads into Mozambique's economy in two sectors}

Agriculture and forestry are priority sectors in Mozambique's development policies and are key to boosting sustainable development and reducing poverty. Both cases highlight issues such as the state's capacity to enhance economic growth and economic diversification, to develop a national economy, to increase the efficiency and accountability of government institutions, and to create opportunities for social development. Often the GoM's rhetoric and policies are not consistent with what is executed in practice. The most relevant agriculture and forestry sectors policies which are meant to promote a sustainable development and growth are often relegated to the second place as the ruling elite prioritises the development of large-scale projects, neglects breaches to the law, and grants privileges to a few of its constituents. Thus, the impact of China's cooperation with Mozambique in these sectors is key to examine the advantages and disadvantages of bilateral engagements and to examine the role Chinese and Mozambican actors' play in shaping outcomes.

A brief note on data collection and analysis: The data used for each case derives from online newspaper articles, published research, official documents and policies, and reports from governmental and non-governmental bodies. The data used for each case is explanatory in nature and relies on the analysis of secondary material. The information provided by different sources was cross-checked to examine whether there were significant differences in the information published, whether any methodological issues arose from the way in which information was produced and circulated, and whether there were any issues concerning the reliability of information sources (Myers et al. 1996: 23-4; Robison, 2004: 384; Mawdsley, 2008; Bräutigam, 2009: 258-9; Bräutigam and Xiaoyang, 2009: 696-7; Bräutigam, 2010: 19). 


\section{China's inroads into Mozambique's agriculture sector}

In the late 1970s, China put a significant emphasis on agriculture reform and development, and on taking peasants out of poverty. At the same time, China aimed "to create the food security, rural stability, surplus income, and labour supply to drive broader industrial development" (Davis and Woetzel, 2011). Priorities and objectives that led to successful agricultural development in China included: agriculture policy reforms, macroeconomic reforms, pro-poor policies, multi-sectoral rural development projects, institutional capacity development, infrastructure construction, technological investment, gradual market liberalisation, credit and finance, internal market integration, micro-level smallholder programmes, and rural industrialisation (Ravallion, 2009: 307-310; Sandrey and Edinger, 2009; Fan et al. 2010: 4-6). In a few decades, China managed to ensure the nation's food security, to improve the nutrition levels of the population, and to reduce the undernourishment and poverty rates (Xiaoyun, no date).

Despite the achievements made in Chinese agriculture, China's experiment has also encountered significant shortcomings or drawbacks. The most important concern environmental degradation, soil erosion, a rise in social and economic inequalities and the continued prevalence of considerable poverty rates in rural areas (Ravallion, 2009: 306; Fan et al. 2010: 3) Furthermore, the decrease of arable land in China has increased the pressure on agricultural land. Similarly, the growing population and rising levels of agricultural imports have forced China to rethink its own food security strategy (Ekman, no date: 15-22; Sandrey and Edinger, 2009: 9). As a result, the possibility of China practicing 'overseas farming' in countries with extensive arable land has been raised. However, this possibility has at times been confused and enmeshed with China's intent to promote agricultural projects abroad, to enhance its 'Going Global' strategy and agriculture-related ventures, and to ensure its own food security (Bräutigam and Xiaoyang, 2009; Hairong and Sautman, 2010).

\section{7 \\ Since China engaged with sub-Saharan African states, agricultural cooperation has been a priority.

Since China engaged with sub-Saharan African states, agricultural cooperation has been a priority (FOCAC, 2006; FOCAC, 2010). On the one hand, the development of agricultural aid projects or partnerships generates the possibility for mutual cooperation, technology transfer and for lessons to be learnt from China's expertise (Hairong and Sautman, 2010: 320-1). At the same time, they set opportunities for Chinese agricultural companies and entrepreneurs to expand their businesses abroad (Bräutigam and Xiaoyang, 2009: 692-3; Fan et al. 2010: 10-2). On the other hand, Chinese investments in agriculture overseas raise concerns over China's potential 'land grab', when considering the wider economic and social implications of land lease for host countries, and the risk of "increasing the vulnerability of traditional subsistence farmers and smallholders" (Bräutigam and Xiaoyang, 2009: 687).

As elsewhere in sub-Saharan Africa, the increasing Sino-Mozambican agricultural cooperation has been developed according to objectives set by China at the FOCAC ministerial meetings and in China's Africa Policy (FOCAC, 2006; Anon. 2007; FOCAC, 2010). In particular, China's commitment to establishing agricultural demonstration centres, enhancing technology and knowledge transfer, financing infrastructure construction, sending technical experts, and promoting technical training programmes 
in "crop seed selection, [and] farming" (Taylor, 2011: 49). Agricultural aid projects have been financed by the Chinese Government, the CADFund, and the Exim Bank of China (Sandrey and Edinger, 2009: 37-9). More specifically, China's agricultural cooperation with Mozambique has been promoted by the following means:

- Chinese government officials and entrepreneurs have visited Mozambique and expressed their interest in promoting agricultural engagements.

- $\quad$ The Chinese Government and Chinese companies have been financing some agriculture projects in Mozambique.

- China has been funding the development of agricultural demonstration centres.

- $\quad$ China has been promoting the transfer of skills and technology and providing technical assistance.

- $\quad$ Chinese experts have been promoting research on new seeds varieties in Mozambique.

- China has granted agricultural machinery to Mozambique.

- Mozambique has promoted the export of agricultural products to China.

1 Sino-Mozambican agricultural cooperation involves a combination of private initiatives and state promoted agricultural aid projects and agriculture-related partnerships.

\section{China's Impact in Mozambique's Agriculture Sector}

Sino-Mozambican agricultural cooperation involves a combination of private initiatives and state promoted agricultural aid projects and agriculture-related partnerships. In practice, Chinese investments in Mozambique's agriculture sector are still insignificant if compared to investments in and imports of other natural and extractive resources (Hon et al. 2010: 79). Agriculture represented 1\% of Chinese FDI to Mozambique in 2007 and an estimated 12\% of Mozambique's total exports to China in 2008 (Chichava, 2010b: 3; Hon et al. 2010: 79). Nonetheless, the potential for China and Mozambique to deepen cooperation in producing cash crops that represent significant agricultural imports for China, such as soybeans, cotton or tobacco, is considerable (Sandrey and Edinger, 2009: 52). Similarly, the potential for Mozambique to draw lessons from China's policymaking practices, agriculture and rural growth policies, farming technologies, institutional capacity building, and to benefit from Chinese investment and financial assistance is significant (Roque, 2009: 11; Sandrey and Edinger, 2009; Ravallion, 2009: 311; Fan et al. 2010: 11-2).

Considering the scale and scope of Sino-Mozambican agricultural cooperation, significant challenges still constrain the potential for Mozambique to benefit from more aid and investment from China (Ekman, no date: 38-40; Kamphuis, 2009: 9). The lack of capacity of the Mozambican state to implement policies and laws effectively, to improve governance quality, to advance institutional capacity, to articulate agricultural policies with rural development, to enhance poverty reduction and to empower smallholders has had substantial negative impact on agricultural development (Ekman, no date; Ravallion, 2009: 311; Savana, 2011b). At the economic level, the lack of much needed state support in policymaking, in infrastructure construction, in 
credit provision, in improving investment conditions and in developing processing facilities, has negatively impacted on the potential of the agricultural sector and discouraged Chinese investment (Alvarenga, 2008: 66; Roque, 2009: 11; Rubinstein, 2009). Poor infrastructure and high shipping costs have been two of the factors identified by Chinese entrepreneurs not to invest in Mozambique: "companies are afraid just to make up a total loss" (Chichava, 2010b: 6).

Simultaneously, the expansion of China's agricultural projects in Mozambique exerts some economic and social implications. In 2008, Loro Horta (somewhat polemically) suggested that China's 'land grab' in the Zambeze valley would turn Mozambique into its 'first agricultural colony' (Horta, 2008). Despite the lack of accuracy in the news, some implications of China's interests in developing and investing in Mozambique's agricultural sector were disclosed (Ekman, no date: 28; Bräutigam and Xiaoyang, 2009: 696-8 and 705-6; Chichava, 2010b: 6-7). Horta's (2008) article raised awareness of the fact that: agreements set at the government level often disregard the interests and rights of local populations; that large land leases can increase cashcrop exports to China when Mozambique still needs food assistance and depends on food imports; and that China's agricultural interests can imply the settlement of Chinese workers in rural areas directly impacting on the livelihoods of local communities. Longer-term issues are also implicated: competition between Mozambican and Chinese producers in local markets; increase of cash-crop production at the expense of food-crop production for local consumption; abandonment of food-crop production for seasonal work in cash crops causing a gap in food-crop production; and a conflict between men and women roles in the division of labour (Bräutigam and Xiaoyang, 2009: 706).

1 Mozambique is faced with the possibility of Chinese investments bringing capital, know-how, technology and market access which can significantly impact on agriculture

To conclude, Mozambique is faced with the possibility of Chinese investments bringing capital, know-how, technology and market access which can significantly impact on agriculture (Alvarenga, 2008: 67) Simultaneously, it is faced with the possibility of Chinese led agriculture projects or land leases putting the food security and livelihoods of rural communities at risk and infringing traditional land rights. Nonetheless, the evidence shows that China's role in Mozambique's agriculture is comparatively insignificant and that other external actors exert a more significant impact on it without the implications of their practices always being considered (Ekman, no date: 31; Franco et al. 2010; AgroNoticias, 2011).

\section{China's Inroads into Mozambique's Forestry Sector}

China is the world's leading importer of unprocessed forest products and exporter of processed woods, furniture and other processed wood materials. China's wood industry grew mainly out of the manufacture of Chinese products for the Chinese and international markets. China's economic boom in the 1990s increased its demand for wood, but the logging ban imposed in the Chuanxi Forest area in 1998 forced Chinese companies to look abroad for their supply of wood products. Hence, China turned to countries like Russia, New Zealand, Papua New Guinea, Thailand, Vietnam and Gabon to import various wood species (Xiufang and Canby, 2011).

By imposing little or no tax on imported raw logs but significant tax on processed 
woods, the government promoted the import of unprocessed logs and secured the sustainability of the national logging industry. China's massive processing capacity did however create disequilibrium in the international market which also, in some less democratic countries, increased illegal logging activities. By importing logs in large quantities and with few taxes, the processing and sale of wood products to the national and international market became relatively cheap (Bossel and Norfolk, 2007; Feijó, 2010). As a result of this trend, China's wood industry reached the highest levels of import, production and export in 2009, importing 113 million $\mathrm{m}^{3}$ of forest products and exporting wood products to a total value of US\$25 billion (Xiufang and Canby, 2011). Such fast dynamics have however raised concerns over the sustainability of logging activities and over the economic, social, and environmental impact of this activity in supplier countries like Mozambique (Mol, 2011).

\section{Even though Mozambique represents less than 1\% of China's total imports of wood per annum, China is its main export partner for wood.

Even though Mozambique represents less than 1\% of China's total imports of wood per annum, China is its main export partner for wood (Bossel and Norfolk, 2007). Mozambique has been exporting wood to China since at least 1997 but the real quantity and value of exports is indeterminate (Table 2).

Table 2 Mozambique's Forest Products Exports to China, 1997-2010

\begin{tabular}{|l|c|c|}
\hline & $\begin{array}{c}\text { Quantity Total }\left(\mathbf{m}^{3}\right) \\
\text { FAOSTAT } \\
\text { (includes round, sawn and plywood, } \\
\text { and other wood products) }\end{array}$ & $\begin{array}{c}\text { Quantity Total }\left(\mathbf{m}^{3}\right) \\
\text { Global Timber }\end{array}$ \\
\hline 1997 & 28,196 & not available \\
\hline 1998 & 15,709 & 14,000 \\
\hline 1999 & 38,137 & 33,000 \\
\hline 2000 & 76,214 & 33,000 \\
\hline 2001 & 65,541 & 45,000 \\
\hline 2002 & 79,685 & 70,000 \\
\hline 2003 & 70,195 & 81,000 \\
\hline 2004 & 70,155 & 81,000 \\
\hline 2005 & 331,065 & 111,000 \\
\hline 2006 & 34,563 & 130,000 \\
\hline 2007 & 13,188 & 219,000 \\
\hline 2008 & 70,294 & 197,000 \\
\hline 2009 & 79,425 & 155,000 \\
\hline 2010 & not available & 219,000 \\
\hline
\end{tabular}


Various practices are endorsed by both Chinese and Mozambican actors which undermine the potential of the forestry sector in Mozambique. In 2007, China's Forestry Administration and the Chinese Ministry of Commerce issued the Guidelines for Sustainable Forest Management by Chinese Companies Operating Outside China, which have reportedly had a positive impact on Chinese activity in countries like Cameroon, but despite efforts to improve Chinese logging activity abroad the practices of Chinese operators in Mozambique are below the legal requirements (Ceruti et al. 2011). Infringements in the forestry sector are not one-sided; Mozambican elites also contribute to the deterioration of conditions for logging activity (Chichava, 2010a: 344-6). In 2006, Catherine Mackenzie's report exposed illegal logging activities carried out by Chinese and Mozambicans in Zambezia province, which has increased significantly. Involvement extends throughout the sector: from simple licence holders to industrial forestry concession holders, from timber buyers to export companies, and includes village leaders, local wood loggers, truck owners, shipping companies, government authorities, customs officers and the police (Mackenzie, 2006: 13-9).

\section{Government officials' involvement in corrupt practices in the timber industry makes the government's rhetoric significantly distinct from the reality.

Mackenzie (2006) shows that a patron-client relation is often established between Chinese financiers and small operators. Whilst the former often end up controlling the commodity chain, the latter often become entrapped into debt and have to secure logs supply to Chinese traders to repay their debts. Small operators use the underpaid workforce in local communities to cut and transport the logs to the ports. They pay bribes to provincial authorities for the acquisition of simple licences, but also to forest officers, village leaders and checkpoint controllers, police and customs officers to under-report and under-invoice over-cutting, mislabel tree species and facilitate the transport of logs from the forests to the ports. On a larger scale, forest concession holders are national investors. They are politically related to Frelimo, therefore to local and provincial government authorities which, in partnership with Chinese operators, harvest and export mostly unprocessed logs to China. At this level, circumventing the law becomes easier.

Government officials' involvement in corrupt practices in the timber industry makes the government's rhetoric significantly distinct from the reality. From the information collected, Mackenzie observes that in 2003 the largest timber export companies in Quelimane were all Chinese: Madeiras Alman, Green Timber, Peter Yu, Timberworld (Chen Kee Meng). Many had local partners connected to the Frelimo party and the Chissano family. As a result of various stakeholders' involvement in the forestry sector and of widespread illegal logging activity, Mackenzie (2006: 17) demonstrates that: a) Chinese timber buyers and operators "have no interest in the sustainable development of the sector" - when the conditions are no longer favourable they will move to other countries; and b) forestry governance laws are often not applied by Mozambican authorities. The political elites put into "direct conflict public responsibilities and private interests" (Mackenzie, 2006: vi). Rather than seeking to move Mozambique up in the value chain, to obtain income from the processing and 
export of processed wood, and to create jobs, the government and Mozambican operators are promoting corrupt practices ${ }^{1}$.

The impact of Mackenzie's report on the Mozambican media, NGOs, and civil society was significant and led to an unofficial national campaign against illegal logging. Criticisms have been widely expressed in the civil-society weblog Diario de um Sociólogo about the illegal practices (Feijó, 2010). The concerns expressed in civil society resulted in the writing of two open letters to Mozambique's president by the academic Carlos Serra and the journalist Marcelo Mosse and the composition of the lyrics for a song about China's illegal extraction of timber by the writer Mia Couto (Feijó, 2010: 6-7). The NGO Justiça Ambiental and the movement Amigos da Floresta have since 2007 researched and discussed the environmental, social and economic impact of illegal logging activity in the central and northern regions of Mozambique, and have examined how these directly relate to governance issues.

\section{IT 1 Therall appraisal, the environmental and social impact, of forest management, processing and export remain poor. Sustainable forest management plans are not implemented.}

In 2007, a report published by Bossel and Norfolk drew attention to the practices in the province of Cabo Delgado. As with the cases in Zambezia province, Chinese operators are involved in financing and buying timber from simple licence holders. Chinese transport companies, for instance Mogid, Mico and Heyne, and shipping companies are involved in transporting timber to the ports and exporting it to China. Of nine companies with approved forest concession licences in 2006, at least one was Chinese, Mofid, and the others export most of the timber harvested to China. From 2000 to 2005, 85\% of the timber harvested in Cabo Delgado had China as its final destination. The overall appraisal, the environmental and social impact, of forest management, processing and export remain poor. Sustainable forest management plans are not implemented. Bribery and corruption facilitate illegal logging which represents significant financial losses to the economy and the state. Deforestation is increasing the negative impact on local livelihoods and on the environment.

The Mozambican media has also investigated and exposed illegal logging activities.

In February 2007, Mozambican newspapers reported that 50 timber containers were held in the port of Pemba, Cabo Delgado, which belonged to the Chinese company Mofid. A fine of 276,745 Meticais (approximately US $\$ 10,482)$ was applied and the wood was stored to be re-sold in public auction (Noticias Lusófonas, 2007). In 2004, Mofid had already been found guilty of fraud for issuing false documents (Noticias Lusófonas, 2007).

In September 2007, in the province of Nampula, the port of Nacala director and two customs officers were suspended for involvement in the falsification of forged export permits for unprocessed logs (Noticias, 2007b).

In November 2007, an investigation enhanced by a multi-disciplinary team found that Aristides Muhate, Director of the Forestry and Wildlife Department in Nampula and son of the Minister of Agriculture, was involved in facilitating business with Chinese companies involved in the illegal export of timber to China. Muhate was forced to leave his post but no charges were made against him (Wamphula Fax, 2007). 
AFRICAN

EAST

ASIAN

AFFAIRS

THE CHINA MONITOR
In December 2007, 543 timber containers were held at Nacala for the attempt to export unprocessed logs illegally. Eight Chinese companies were found guilty, the China HK Development Group among them, and a fine of $13,503,240$ Meticais (approximately US\$511,486) was issued (Noticias, 2007c).

In October 2008, 53 timber containers with 5,400 round logs were held in the port of Mocimboa da Praia, Cabo Delgado, for the illegal export of unprocessed wood. The containers belonged to the Chinese companies MT International and Alman, who were charged with a fine of 486 million Meticais (US\$1.8 million) (Araujo, 2008).

In July 2011, 561 timber containers were held at Nacala with round wood logs of unprocessed pau-preto, pau-rosa, and sandalo. The containers belonged to Chinese companies: Casa Bonita International, Zheng Long International, Mozambique Trading Ltd, Yizhou, Tong Fa Ltd, Chanate Ltd, Senyu and Verdura Ltd. As a result, the Regional Customs Director of Nacala was dismissed, but no other sanctions were applied (Savana, 2011a).

In sum, the forestry sector has raised numerous issues; from compliance with forest law to environmental concerns, sustainable extraction of logs, and the development of wood processing industry. Furthermore, despite the media, local groups and NGOs disclosing cases of non-transparent logging activity, illegal timber export, and detention of timber containers at Mozambican ports, it is not always clear that companies that infringe the law pay the fines and no major follow ups are made by the government. The measures taken to contravene illegal logging are superficial and have no major consequences for the perpetrators.

11 In sum, the forestry sector has raised numerous issues; from compliance with forest law to environmental concerns, sustainable extraction of logs, and the development of wood processing industry.

\section{Conclusion}

In the recent decades, the GoM has adopted policies to develop the agriculture and forestry sectors. Traditional donors have disbursed substantial sums of aid, provided technical advice and imposed conditions in the attempt to enhance development. In both cases it was observed that policies still need to be effectively implemented for real progress to be made.

More recently, Mozambique has had the opportunity of benefiting from Chinese aid, trade and investment. Agriculture and forestry are two areas in which China has become increasingly involved. In the case of agriculture, China's aid and investment offer a practical approach to agricultural development. China's assistance has focused on: promoting technology and knowledge transfer through the agricultural demonstration centres it builds, increasing cereal production by researching and testing new seed varieties, and expanding Mozambique's processing capacity and infrastructure. The current pattern of Chinese involvement could promote mechanisms to combat poverty and enhance development but the overall level of Chinese investment in agriculture is still insignificant. Notwithstanding, whether China does or does not increase its agricultural investments, the GoM is liable for determining and 
enforcing national policies and for relegating personal interests to the bottom of its priorities. In the case of forestry, logging is largely beyond the control of state authority. The weak state apparatus enables Mozambican economic and political elites alongside Chinese entrepreneurs to participate illegally in this activity and to benefit from it. This is possibly the most problematic issue of Sino-Mozambican cooperation. The differences between the laws, regulations, strategies and development objectives set by the GoM and what occurs in practice are evident. The GoM does little to prevent its elites at the national and local level, as well as Chinese operators, from appropriating state resources illegally. The interests of government officials involved in the timber industry clash directly with their official obligations and with government policies and strategies. Government controls become ineffective as a result of personal interests and corruption subverting the state machinery. On the whole, Mozambique's weak forest governance, the weak performance of political and institutional actors, the lack of strategic thinking in promoting sustainable forestry management, in developing the processing industry, creating jobs and extending social welfare, negatively impact on development. Forestry sector policies are subverted by China's policies, by Chinese operators' modus operandi, by the personal interests of Mozambican elites and by petty corruption promoted by local government officials.

To conclude, asymmetries in bilateral cooperation show that relations do not challenge inefficient and corrupt government structures. China exerts very limited interference in the internal affairs of Mozambique and the ruling elite sustains a form of governance that both undermines the rule of law and disregards means to increase national cohesion and state legitimacy. The GoM undertakes businesses that do not directly benefit local communities or allow them to participate in negotiations. This provides ruling elites with the means to sustain patron-client networks; it maintains the exploration of the few natural resources but often diverts revenue away from socioeconomic reinvestment.

\section{End Notes}

1 In 2009, Mackenzie's 2006 report was revised. In the new report, Mackenzie and Ribeiro (2009) observe no improvements in any of the key areas for sustainable management of forest resources and development of the processing industry. They note that the number of simple licences issued decreased from 863 in 2004 to 113 in 2007, but illegal licensing increased and unlicensed logging and overcutting remain common practices. The number of forest concession contracts has increased from 2 in 2004 to 32 in 2008 and the quality of concession management plans remains poor. The cutting cycle plans are too short and reforestation plans are poorly implemented. From 2001 to 2007, only 25 nurseries were created to grow native species covering an estimated area of 123 hectares. Records with cumulative and geographically referenced information of species and volumes cut are not systematically reported. There is a relative increase in the number of checkpoints, however the number of staff has decreased and more checkpoints do not translate as more law enforcement but as further rent-seeking behaviour. The existent sawmills have not been upgraded and continue to produce only rough sawn planks. On the whole, "corruption, arrogance and mismanagement continue and are seriously undermining the rule of law, accountability of government and future of the forest sector" (Mackenzie and Ribeiro, 2009: 27). 


\section{References}

Abrahamsson, H. and Nilsson, A. (1995) Mozambique, the Troubled Transition: from Socialist Construction to Free Market Capitalism, London: Zed Books

AgroNoticias (2011) 'China e Suécia na "corrida à terra" em Moçambique', AgroNoticias, 8 June, available online at http://www.agroportal.pt/x/agronoticias/2011/06/08f.htm, accessed 28 October 2011

Alden, Chris (2001) Mozambique and the Construction of the New African State, Hampshire: Palgrave Macmillan

Alvarenga, Daniel (2008) 'China's Economic Involvement in Mozambique and Prospects for Development: An Analysis of the Processes and Impacts of Major Recent Investments', MA, University of Stellenbosch

Anon. (2007) 'White Paper on China's African Policy', China Report, 43 (3): 375-391

Barkin, Samuel and Cronin, Bruce (1994) 'The State and the Nation: Changing Norms and the Rules of Sovereignty in International Relations', International Organization, 48 (1): $107-130$

Araujo, Manuel de (2008) 'Porto de Mocimboa da Praia: Madeira apreendida vai a hasta publica', 3 October, available online at http://manueldearaujo.blogspot.com/2008/10/porto-de-mocmboa-da-praia.html, accessed 10 September 2011

Arndt, C., Jones, S. and Tarp, F. (2007) 'Aid and Development: The Mozambican Case', Discussion Papers, Department of Economics, University of Copenhagen, available online at http://www.econ.ku.dk/ftarp/workingpapers/Docs/Aid\%20and\%20Development_The\% 20Mozambican\%20Case.pdf, accessed 12 September 2011

Batley, Richard (2005) 'Mozambique: the Costs of 'Owning' Aid', Public Administration and Development, 25 (5): 415-424

Bossel, A. and Norfolk, S. (2007) 'Global Forest Product Chains: A Mozambique case study identifying challenges and opportunities for China through a wood commodity chain sustainability analysis', Maputo: Terra Firma Lda for IIED, in: Sun, C. Chen, L., Chen, L., Han, L., Bass, S. (2008) 'Global Forest Product Chains: Identifying challenges and opportunities for China through a global commodity chain sustainability analysis', Manitoba: MOFCOM, IISD \& SECO

British Broadcasting Corporation (BBC) (2011) 'The Chinese Are Coming', BBC, 24 February, available online at http://www.bbc.co.uk/programmes/b00ykxg9, accessed 24 February 2011

Bräutigam, Deborah (2010) 'China, Africa and the International Aid Architecture', Working Paper No. 107, Tunis: African Development Bank

Bräutigam, Deborah (2009) The Dragon's Gift: The Real Story of China in Africa, Oxford: Oxford University Press

Bräutigam, D. and Xiaoyang, T. (2009) 'China's Engagement in African Agriculture: 'Down to the Countryside', The China Quarterly, 199 (1):686-706Broadman, Harry (2006) Africa's Silk Road: China and India's New Economic Frontier, 
Publisher: World Bank, The

Ceruti, P.O., Assembe-Mvondo, S., German, L. and Putzel, L. (2011) 'Is China Unique? Exploring the Behaviour of Chinese and European Firms in the Cameroonian Logging Sector, International Forestry Review, 13(1): 23-33

Chichava, Sérgio (2010a) 'Moçambique na Rota da China: Uma Oportunidade para o Desenvolvimento?' in: Brito, L., Castel-Branco, C.N., Chichava, S., and Francisco, A. (2010) Desafios para Moçambique 2010, Maputo: IESE

Chichava, Sergio (2010b) 'China in Mozambique's Agriculture Sector: Implications and Challenges', Celebrating the 10th Anniversary of the Establishment of the Forum on China-Africa Co-operation (FOCAC), Johannesburg, South Africa, 18-19 November 2010

Davis, S. and Woetzel, J. (2011) 'How Africa Can Learn from Chinese Agriculture', How We Made it in Africa, 20 April, available online at http://www.howwemadeitinafrica.com/how-africa-can-learn-from-chineseagriculture/9333/, accessed 26 October 2011

Ekman, Sigrid-Marianella Stensrud (no date) 'Leasing Land Overseas: A Viable Strategy for Chinese Food Security? Opportunities and Risks of Chinese Agricultural Investments in Mozambique', available online at http://www.ispu.ac.mz/por/content/download/7906/40283/file/Opportunities\%20and\%2 Orisks\%20of\%20Chinese\%20Agricultural\%20Investments\%20in\%20Mozambique.pdf, accessed 27 October 2011

Fan, S., Nestorova, B., Olofinbiyi, T. (2010) 'China's Agricultural and Rural Development: Implications for Africa', Food Security and Rural Development, meeting in Bamako, April 27-28, available online at http://www.ifpri.org/sites/default/files/publications/chinaafricadac.pdf

Feijó, João (2010) 'Mozambican perspectives about China in Africa - a study from the discourses published in a Mozambican weblog' available online at http://www.ispu.ac.mz/por/Actividades/Ensino/Guias-de-

Avaliacao/Observat\%C3\%B3rio-Sobre-Meio-

Rural/Reposit\%C3\%B3rio/Coopera\%C3\%A7\%C3\%A3o/China-emMo\%C3\%A7ambique-e-\%C3\%81frica_Jo\%C3\%A3o-Feij\%C3\%B3, accessed 28 September 2011

Forum on China-Africa Cooperation (FOCAC) (2010) 'Forum on China-Africa Cooperation Sharm el Sheik Action Plan (2010-2012)', available online at http://www.focac.org/eng//tda/dsjbzjhy/hywj/t626387.htm, accessed 22 June 2011

Forum on China-Africa Cooperation FOCAC (2006) 'Forum on China-Africa Cooperation Beijing Action Plan (2007-2009)', available online at http://www.focac.org/eng/ltda/dscbzjhy/DOC32009/t280369.htm, accessed 20 September 2011

Franco, J., Levidow, L., Fig, D., Goldfarb, L., Hönicke, M. and Mendonça, M.L. (2010) Assumptions in the European Union Biofuels Policy: Frictions with Experiences in Germany, Brazil and Mozambique', Journal of Peasant Studies, 37 (4): 1-32

Gomes, Ana Maria (2007) 'Draft Report on China's policy and its effects on Africa' available online at http://www.europarl.europa.eu/meetdocs/2004_2009/documents/pr/697/697015/6970 15en.pdf, accessed 17 June 2011 
Hairong, Yan and Sautman, Barry (2010) 'Chinese Farms in Zambia: From Socialist to “Agro-Imperialist" Engagement?', African and Asian Studies, 9 (3): 307-333

Hall, M. and Young, T. (1997) Confronting Leviathan: Mozambique since Independence, London: C. Hurst \& Co.

Hanlon, Joseph (1996) Peace without Profit: How the IMF Blocks Rebuilding in Mozambique, Publisher: Heinemann

Hanlon, Joseph (1991) Mozambique: Who Calls the Shots, London: James Currey Ltd Hon, T., Jansson, J., Shelton, G., Haifang, L., Burke, C. and Kiala, C. (2010) 'Evaluating China's FOCAC commitments to Africa and mapping the way ahead', Stellenbosch: Centre for Chinese Studies, University of Stellenbosch

Horta, Loro (2008) 'The Zambezi Valley: China's First Agricultural Colony?', available online at http://csis.org/blog/zambezi-valley-china\%E2\%80\%99s-first-agriculturalcolony, accessed 22 July 2010

Kamphuis, Anneke (2009) 'Policy Watch: The Potential for Chinese Alleviation of Fundamental Constraints Facing Sub-Saharan African Smallholder Farmers', The China Monitor, Issue 40, Stellenbosch: Centre for Chinese Studies, University of Stellenbosch

Latham, S. F. (1981) 'About-turn in Mozambique?', World Today, 37 (2): 69-73

Mackenzie, Catherine (2006) 'Forest Governance in the Zambezia, Mozambique: Chinese Takeaway', available online at http://www.illegallogging.info/uploads/Mozambique_China.pdf, accessed 20 May 2011

Mackenzie, Catherine and Ribeiro, Daniel (2009) 'Tristezas Tropicais: More Sad Stories from the Forests of Zambézia', available online at http://www.lllegallogging.info/uploads/TristezasTropicaisFINALEnglish22May.pdf, accessed 26 April 2012

Manji, Firoze and Marks, Stephen (eds) (2007) African Perspectives on China in Africa, Oxford: Fahamu

Manning, Carrie L. (2002) The Politics of Peace in Mozambique: Post-Conflict Democratization, 1992-2000, Westport: Praeger Publishers

Mawdsley, Emma (2008) 'Fu Manchu versus Dr Livingstone in the Dark Continent? Representing China, Africa and the West in British Broadsheet Newspapers', Political Geography, 27 (5): 509-529

Mol, Arthur P.J. (2011) 'China's Ascent and Africa's Environment', Global Environmental Change, 21 (3): 785-794

Myers, Garth, Klak, Thomas and Koehl, Timothy (1996) 'The Inscription of Difference: News Coverage of the Conflicts in Rwanda and Bosnia', Political Geography, 15 (1): $21-46$

Newitt, Malyn (2002) 'Mozambique' in: Chabal, P. (ed), Birmingham, D., Forrest, J., Newitt, M., Seibert, G., Andrade, E.S. (2002) A History of Postcolonial Lusophone Africa, London: C. Hurst \& Co.

Notícias (2007b) 'Exportação de Madeira em Nacala: Suspenso chefe distrital de actividades económicas', Noticias, 28 September, available online at http://macua.blogs.com/moambique_para_todos/2007/09/exportao-de-mad.htlm, 
accessed 10 September 2011

Noticias (2007c) 'Destinada a exportação ilegal Tribunal Aduaneiro ordena devolução da madeira apreendida', Noticias, 8 December, available online at http://www.imensis.co.mz/news/anmviewer.asp?a=11113, accessed 10 September 2011

Notícias Lusófonas (2007) 'Apreendidos mais de 1.100 toros de madeiras preciosas a empresa chinesa', Noticias Lusófonas, 2 February, available online at http://macua.blogs.com/moambique_para_todos/2007/02/apreendidos_mai.html, accessed 10 September 2011

Ottaway, Marina (1988) 'Mozambique: From Symbolic Socialism to Symbolic Reform', The Journal of Modern African Studies, 26 (2): 211-226

Pitcher, M. A. (2002) Transforming Mozambique: The Politics of Privatization, 19752000, Cambridge: Cambridge University Press

Plank, David N. (1993) 'Aid, Debt, and the End of Sovereignty: Mozambique and Its Donors', The Journal of Modern African Studies, 31 (3): 407-430

Ravallion, Martin (2009) 'Are There Lessons for Africa from China's Success against Poverty', World Development, 37 (2): 303-313

Robison, Bridget (2004) 'Putting Bosnia in its Place: Critical Geopolitics and the Representation of Bosnia in the British Print Media', Geopolitics, 9 (2): 378-401

Roque, Paula C. (2009) 'China in Mozambique: A Cautious Approach Country Case Study', South African Institute of International Affairs Occasional Paper No 23, available online at http://www.saiia.org.za/images/stories/pubs/occasional_papers/saia_sop_23_roque_2 0090218_en.pdf, accessed 27 August 2010

Rubinstein, Carl (2009) 'China's eye on African agriculture', Asia Times Online, 2 October, available online at http://www.atimes.com/atimes/China_Business/KJ02Cb01.html, accessed 28 October 2011

Sandrey, Ron and Edinger, Hannah (2009) 'The Relevance of Chinese Agricultural Technologies for African Smallholder Farmers: Agricultural Technology Research in China', Stellenbosch: Centre for Chinese Studies, University of Stellenbosch

Savana (2011a) 'Uma vez mais - Generais no tráfico de madeira', Savana, 22 July, available online at

http://macua.blogs.com/moambique_para_todos/2011/07/uma-vez-mais-.html, accessed 10 September 2011

Savana (2011b) 'Porquê a prioridade da agricultura e do meio rural', Savana, 22 July, available online at http://macua.blogs.com/moambique_para_todos/2011/07/porqu\%C3\%AA-aprioridade-da-agricultura-e-do-meio-rural.html, accessed 28 October 2011

Taylor, Ian (2011) The Forum on China-Africa Cooperation (FOCAC), Abingdon: Routledge

Wamphula Fax (2007) 'Exportação llegal de Madeira Envolvia Filho de Ministro', Wamphula Fax, 9 November, available online at http://macua.blogs.com/moambique_para_todos/2007/11/exportao-ilegal.html, 
AFRICAN

EAST

ASIAN

AFFAIRS

THE CHINA MONITOR accessed 10 September 2011

Xiaoyun, Li (no date) 'What Can Africa Learn From China's Success in Agriculture?', International Poverty Reduction Centre in China, available online at http://www.iprcc.org.cn/userfiles/file/Li\%20Xiaoyun-EN\%282\%29.pdf, accessed 31 October 2011

Xiufang, S. and Canby, K. (2011) 'Baseline Study 1, CHINA: Overview of Forest Governance, Markets and Trade', available online at http://forestindustries.eu/content/baseline-study-1-china-overview-forest-governancemarkets-and-trade, accessed 28 September 2011

Mafalda Ferreira Piçarra recently finished an MPhil in Politics at the University of Bristol. The MPhil research concerned the analysis of China's increasing involvement in Mozambique's agriculture, forestry and energy sectors, and the examination of the ways in which China impacts on different elements of Mozambique's empirical sovereignty. 